\title{
Modeling Thermal Part of Sulfur Recovery Unit and Simulation Based Analysis of Effects of Air Temperature on Entire Plant
}

\author{
Oguzhan Dogru', Begum Guzel², Gamze IS², Gizem Kusoglu¹, Mehmet Yagci', Murat Kolbasi², Gorkem Ogur ${ }^{2}$ \\ and Erdogan Alper ${ }^{3 *}$ \\ ${ }^{1}$ Turkish Petroleum Refineries Co. (TÜPRAȘ), RED Centre, GuneyMah. Petrol Cad, 41790, Korfez, Kocaeli, Turkey \\ ${ }^{2}$ Turkish Petroleum Refineries Co. (TÜPRAŞ), Izmit Refinery, GuneyMah. Petrol Cad, 41790, Korfez, Kocaeli, Turkey \\ ${ }^{3}$ Department of Chemical Engineering, Hacettepe University, Beytepe Campus Universiteler Mahallesi, 1596. Sok, 06800, Ankara, Turkey
}

\section{Article Info}

*Corresponding author:

Erdogan Alper

Department of Chemical Engineering Hacettepe University

Beytepe Campus Universiteler Mahallesi

1596. Sok, Ankara, Turkey

E-mail: ealper@hacettepe.edu.tr

Received: November 12, 2018

Accepted: November 29, 2018

Published: December 6, 2018

Citation: Dogru O, Guzel B, Gamze IS, et al. ModelingThermal Part of Sulfur Recovery Unit and Simulation Based Analysis of Effects of Air Temperature on Entire Plant. Int J Petrochem Res. 2018; 2(3): 223-229. doi: $10.18689 / \mathrm{jjpr}-1000139$

Copyright: @ 2018 The Author(s). This work is licensed under a Creative Commons Attribution 4.0 International License, which permits unrestricted use, distribution, and reproduction in any medium, provided the original work is properly cited.

Published by Madridge Publishers

\begin{abstract}
Sulfur in feedstocks are increasing steadily. Consequently, changes in regulations force industrial companies to operate Sulfur Recovery Units more efficiently. An industrial Sulfur Recovery Unit of TUPRAS, Turkey was modelled by Matlab by using simplified kinetics. Proposed model was validated with the industrial data of TUPRAS. The model represents the important species with minute deviation. According to the model proposed, conversion and recovery were found to be $65.24 \%$ and $86.88 \%$, respectively; where they were calculated to be $64.91 \%$ and $82.72 \%$ in design case.

Moreover, effects of air temperature were studied in this work. According to the simulation results, up to $\$ 13,200 /$ year can be saved by removing preheating. Because carbon content is essential in gas mixture, effects of $\mathrm{COS}$ and $\mathrm{CS}_{2}$ on catalytic part after this modification are found to be negligible in short term. This design change also increases the sulfur production by about $600 \mathrm{~kg} /$ day. On the other hand, amount of $\mathrm{COS}, \mathrm{CS}_{2^{\prime}} \mathrm{H}_{2} \mathrm{~S}$ released from Selective Oxidation Reactor would be enhanced from 25 to 31 ppmmol, which increase overall $\mathrm{SO}_{2}$ emission from incinerator.
\end{abstract}

Keywords: Sulfur Recovery Unit, Modeling, Simulation

\section{Introduction}

Oil refineries and gas plants process enormous amounts of feedstock to obtain valuable products such as; fuel for vehicles, raw material for petrochemical industry. Recent regulations forced these sectors to lower the sulfur ingredient of both products and waste streams [1], significantly. On the other hand; beside their low cost, "opportunity crudes" with various compositions and increase in the sulfur content of the feed stocks [2] became pain in the neck when it comes to processing the crude oil. Moreover, because of the developing technology and constant demand [3], worldwide sulfur import and export values were halved in 4 years $[4,5]$. Above mentioned progresses faced companies to treat acid gas more effectively to reduce the emissions and operational costs.

There are several methods; including catalytic, electrochemical processes [6]; to convert $\mathrm{H}_{2} \mathrm{~S}$ into non-toxic derivations of sulfur. For industries with high capacity and high concentration, the most widely used technique is Claus Process, in which acid gas is passed through thermal and catalytic reactors to obtain elemental sulfur and steam. Figure 1 represents a Modified Claus Process Configuration [7-15]. 
Thermal part is the first medium that mixture of effluent compounds pass through and consists of a thermal reactor (TR) and a waste heat boiler (WHB). Thermal reactor breaks down most of the waste gas; including mainly $\mathrm{H}_{2} \mathrm{~S}_{1} \mathrm{NH}_{3^{\prime}}$ water, and essentially mercaptans, paraffins, olefins, carbondioxide and other inert gases; at that point temperature may elevate up to $1500 \mathrm{~K}$ and HP steam is obtained by means of WHB. Meanwhile, acid gas becomes extremely corrosive and leads cracks within the refractory. And the consequences may be catastrophic. On the other hand, temperature is one of the most critical parameters because it regulates the kinetics and is able to shift conversion towards both sides. Composition is another parameter that affect the products and hence, emissions. And finally, steam obtained from WHB is used in heat exchangers and electricity production. There by, it is economically beneficial to control and increase the energy efficiency. Summing these up, importance of modeling thermal part becomes undeniable [16-28].

After, acid gas proceeds towards catalytic part, in which substitution and hydrolysis processes are observed on Titania or Alumina catalysts unlike thermal part, in which oxidation processes take place without any catalyst. Catalytic part consists of two or three catalytic beds connected in series, generally. Some plants may have further treatment units in order to meet the demand of strict environmental regulations, which limit $\mathrm{H}_{2} \mathrm{~S}$ conversion to minimum of $99 \%$ levels. These additional systems are told to enhance the sulfur recovery more than $99.9 \%$.

At the end, remaining gas is moved to incinerator to destroy S-containing molecules (e.g. $\mathrm{COS}, \mathrm{CS}_{2^{\prime}} \mathrm{H}_{2} \mathrm{~S}$ ) into $\mathrm{SO}_{2}$. $\mathrm{SO}_{x}$ and $\mathrm{NO}_{x}$ formed are released to atmosphere.

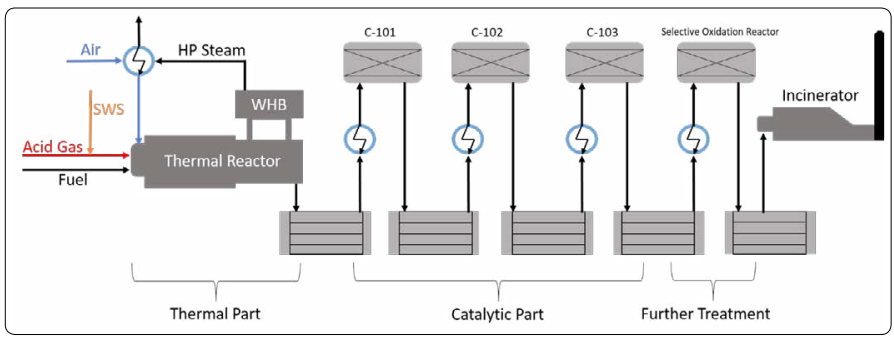

Figure 1. Modified Claus Process for acid gas with ammonia treatment.

$\mathrm{H}_{2} \mathrm{~S}$ conversion in these parts can be shown as:

$\mathrm{H}_{2} \mathrm{~S}+1.5 \mathrm{O}_{2} \rightarrow \mathrm{SO}_{2}+\mathrm{H}_{2} \mathrm{O}$

During reaction (1), $1 / 3$ of $\mathrm{H}_{2} \mathrm{~S}$ is converted into $\mathrm{SO}_{2}$.

$2 \mathrm{H}_{2} \mathrm{~S}+\mathrm{SO}_{2} \rightarrow 1.5 \mathrm{~S}_{2}+2 \mathrm{H}_{2} \mathrm{O}$

In reaction (2), 2/3 of $\mathrm{H} 2 \mathrm{~S}$ combines with $\mathrm{SO}_{2}$ produced to form elemental sulfur.

In the $T R$, pressure range isabout $1.80 \mathrm{~kg}-\mathrm{f} / \mathrm{cm} 2$ and temperature varies between $1300-1500 \mathrm{~K}$ in order to destroy undesired molecules but the refractory.

To maintain sufficient sulfur recovery, lower emissions and produce higher energy within certain limitations while considering safety and sustainability, the system should be operated carefully. A reliable model is necessary to reflect the characteristics of the processes. Modeling is also crucial for human and equipment safety, to study capacity status and to investigate environmental impacts.

\section{Modeling Thermal Part}

Elements of thermal part are thermal reactor, waste heat boiler and sulfur condenser. Inlet streams are acid gas (AG), gas from sour water stripper (SWS) and air. AG comes from Amine Gas Treatment Unit and is composed mainly of $\mathrm{H}_{2} \mathrm{~S}$ (>90\%). SWS gas contains $40 \% \mathrm{H}_{2} \mathrm{~S}, 40 \% \mathrm{NH}_{3}$ and $20 \% \mathrm{H}_{2} \mathrm{O}$. $A G$ and SWS is mixed before being fed to the furnace. Air can be enriched by oxygen supply. In this work, air is not enriched and carries $21 \% \mathrm{O}_{2}$. table 1 shows the properties of inlet streams of one of SRUs in TUPRAS, Izmit Refinery.

Reactor was modelled by using Fourth Order Runge-Kutta Method by assuming;

- Steady state process,

- Fully developed turbulent and plug flow regime (due to high flow rate),

- Ideal gas mixture (due to high temperature, low pressure),

- Adiabatic reactor (due to furnace refractory),

- Absence of radial transport,

- Absence of fouling.

Table 1. Properties of inlet feed (air and acid gas mixture) to the Thermal Reactor, Izmit Refinery, Tupras

\begin{tabular}{|c|c|c|}
\hline Property & Acid Gas + SWS & Air \\
\hline $\mathrm{H}_{2} \mathrm{~S} \%$ & 77.98 & 0.00 \\
\hline $\mathrm{NH}_{3} \%$ & 10.80 & 0.00 \\
\hline $\mathrm{H}_{2} \%$ & 0.05 & 0.00 \\
\hline $\mathrm{CO}_{2} \%$ & 0.50 & 0.03 \\
\hline $\mathrm{H}_{2} \mathrm{O} \%$ & 10.40 & 4.26 \\
\hline $\mathrm{CH}_{4} \%$ & 0.05 & 0.00 \\
\hline $\mathrm{O}_{2} \%$ & 0.00 & 20.06 \\
\hline $\mathrm{N}_{2} \%$ & 0.00 & 74.76 \\
\hline $\mathrm{Ar} \%$ & 0.00 & 0.89 \\
\hline Impurities \% & 0.22 & 0.00 \\
\hline Total & 100.00 & 100.00 \\
\hline Flow Rate $(\mathrm{kmol} / \mathrm{h})$ & 353.80 & 762.74 \\
\hline Temperature $\left[{ }^{\circ} \mathrm{C}\right]$ & 81 & 210 \\
\hline Pressure $\left(\mathrm{kg} / \mathrm{cm}^{2}-\mathrm{g}\right)$ & 0.7 & 0.7 \\
\hline
\end{tabular}

Mass balance for PFR for each component $\mathrm{i}(\mathrm{i}=1: \mathrm{N})$ is:

$\frac{d F_{i}}{d V}=F_{i_{0}}-F_{i}+\int_{i=1}^{N} r_{i} d V$

Energy balance for PFR is:

$\frac{d T}{d V}=\frac{\sum\left(-r_{i}\right)\left(-\Delta H_{r x n}\right)}{\sum F_{0} C_{p 0}}$

$\Delta H_{r x n}(T)=\Delta H_{r x n}\left(T_{r e f}\right)+\Delta C_{p}(T)$

$\Delta C_{p}(T)=\Delta a+\Delta b T+\Delta c T^{2}+\Delta d T^{3}+\Delta e T^{3}+\cdots$

For equation $6, \Delta a=\sum a_{\text {products }}-\sum a_{\text {reactants }}$.

Model results for the composition of important species and temperature profile within the reactor are shown in figure 2 and figure 3 , respectively. 

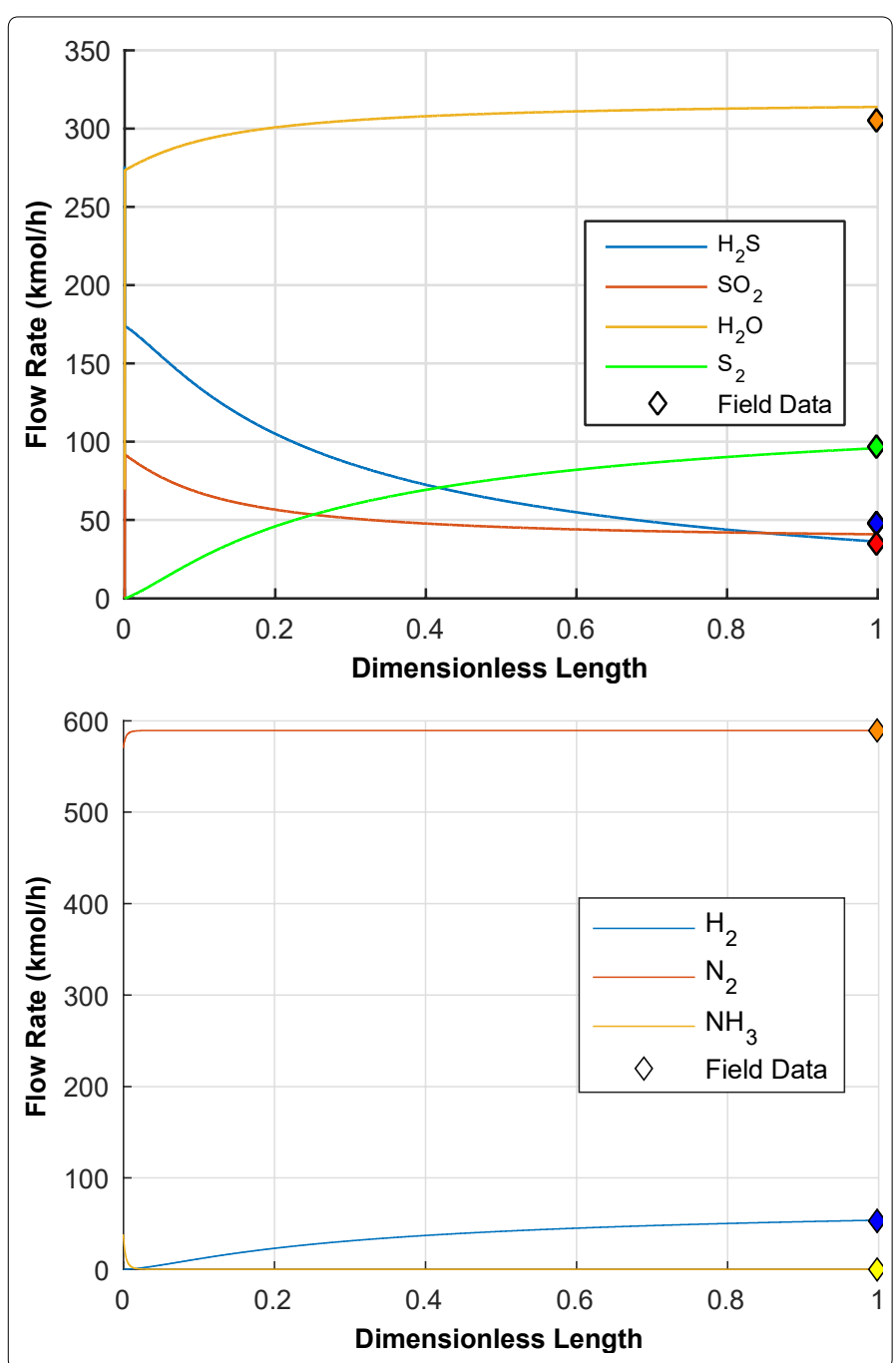

Figure 2a. $\mathrm{H}_{2} \mathrm{~S}, \mathrm{SO}_{2^{\prime}} \mathrm{H}_{2} \mathrm{O}$ and $\mathrm{S}_{2^{\prime}}$ (b) $\mathrm{H}_{2^{\prime}} \mathrm{N}_{2}$ and $\mathrm{NH}_{3}$ composition profiles along the Reaction Furnace (RF)

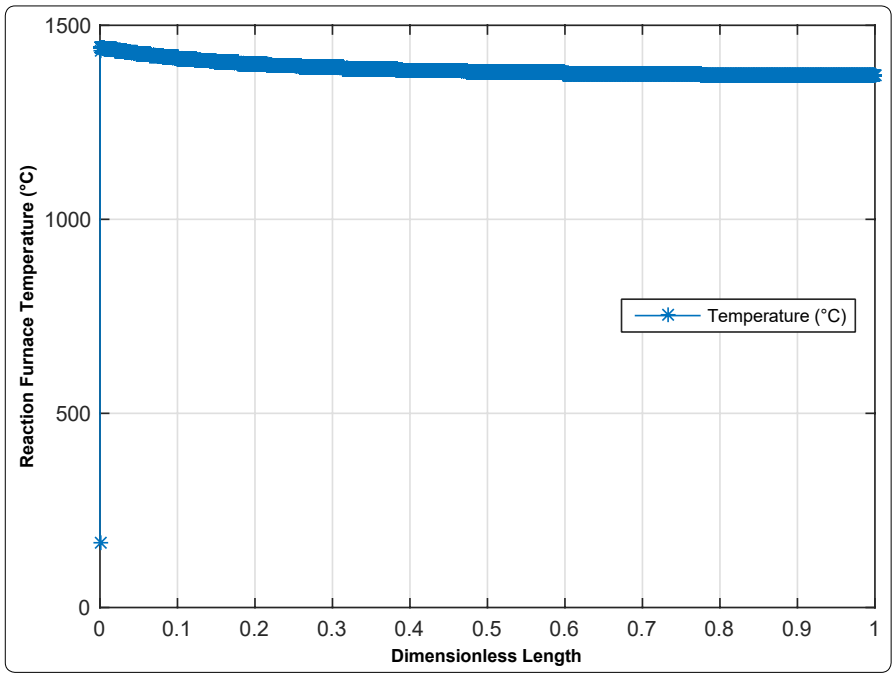

Figure 3. Temperature profile along the Reaction Furnace (RF)

According to figure 2 (a), most of the $\mathrm{H}_{2} \mathrm{~S}$ is oxidized then combined with $\mathrm{SO}_{2}$ to yield $\mathrm{S}_{2}$. As by product, $\mathrm{H}_{2} \mathrm{O}$ is formed. figure 2 (b) shows that all of the $\mathrm{NH}_{3}$ is reacted to $\mathrm{N} 2$ and $\mathrm{H}_{2}$. According to figure 3, Temperature rises immediately at the very beginning of the reactor, due to highly exothermic reactions. After a while, temperature declines smoothly due to endothermic reactions. This temperature decrease enhances combination (e.g. COS formation) reactions.
Table 2. List of Reactions used for Modeling

\begin{tabular}{|c|c|c|c|}
\hline $\begin{array}{c}\text { Rxn. } \\
\#\end{array}$ & Reaction Equation & Reaction Kinetics & $\begin{array}{c}\text { Ref. } \\
\#\end{array}$ \\
\hline 1 & $\mathrm{H}_{2} \mathrm{~S} \leftrightarrow \mathrm{H}_{2} \mathrm{~S}+\frac{1}{2} \mathrm{~S}_{2}$ & $r_{H_{2} S}=-A_{f} \exp \left(-\frac{E_{a_{f}}}{R T}\right) C_{H_{2} S} C_{S_{2}}^{0.5}+A_{r} \exp \left(-\frac{E_{a_{r}}}{R T}\right) C_{H_{2}} C_{S_{2}}$ & 8 \\
\hline 2 & $2 \mathrm{H}_{2} \mathrm{~S}+\mathrm{SO}_{2} \leftrightarrow \frac{3}{2} S_{2}+2 \mathrm{H}_{2} \mathrm{O}$ & $r_{H_{2} S}=-A_{f} \exp \left(-\frac{E_{a_{f}}}{R T}\right) C_{H_{2} S} C_{S O_{2}}^{0.5}+A_{r} \exp \left(-\frac{E_{a_{r}}}{R T}\right) C_{H_{2} O} C_{S_{2}}^{0.75}$ & 9 \\
\hline 3 & $\mathrm{H}_{2} \mathrm{~S}+\frac{3}{2} \mathrm{O}_{2} \rightarrow \mathrm{SO}_{2}+\mathrm{H}_{2} \mathrm{O}$ & $r_{H_{2} S}=-A \exp \left(-\frac{E_{a}}{R T}\right) C_{H_{2} S} C_{O_{2}}^{1.5}$ & 8 \\
\hline 4 & $\mathrm{CH}_{4}+2 \mathrm{~S}_{2} \rightarrow \mathrm{CS}_{2}+2 \mathrm{H}_{2} \mathrm{~S}$ & $r_{C S_{2}}=A \exp \left(-\frac{E_{a}}{R T}\right) C_{H_{2} S} C_{O_{2}}^{1.5}$ & 10 \\
\hline 5 & $\mathrm{CH}_{4}+\frac{3}{2} \mathrm{O}_{2} \rightarrow \mathrm{CO}+2 \mathrm{H}_{2} \mathrm{O}$ & $r_{C H_{4}}=-A \exp \left(-\frac{E_{a}}{R T}\right) C_{C H_{4}}^{0.7} C_{O_{2}}^{0.8}$ & 11 \\
\hline 6 & $\mathrm{C}_{2} \mathrm{H}_{6}+\frac{5}{2} \mathrm{O}_{2} \rightarrow 2 \mathrm{CO}+3 \mathrm{H}_{2} \mathrm{O}$ & $r_{C_{2} H_{6}}=-A \exp \left(-\frac{E_{a}}{R T}\right) C_{C_{2} H_{6}}^{0.1} C_{O_{2}}^{1.65}$ & 11 \\
\hline 7 & $\mathrm{C}_{3} \mathrm{H}_{8}+\frac{7}{2} \mathrm{O}_{2} \rightarrow 3 \mathrm{CO}+4 \mathrm{H}_{2} \mathrm{O}$ & $r_{C_{3} H_{8}}=-A \exp \left(-\frac{E_{a}}{R T}\right) C_{C_{3} H_{8}}^{0.1} C_{O_{2}}^{1.65}$ & 11 \\
\hline 8 & $\mathrm{CO}+\frac{1}{2} \mathrm{O}_{2} \leftrightarrow \mathrm{CO}_{2}$ & $r_{C O}=-A_{f} \exp \left(-\frac{E_{a_{f}}}{R T}\right) C_{C O} C_{H_{2 O}}^{0.5} C_{O_{2}}{ }^{0.25}+A_{r} \exp \left(-\frac{E_{a_{r}}}{R T}\right) C_{C O_{2}}$ & 12 \\
\hline 9 & $\mathrm{CO}+\frac{1}{2} S_{2} \leftrightarrow \operatorname{COS}$ & $r_{C O S}=-A_{f} \exp \left(-\frac{E_{a_{f}}}{R T}\right) C_{C O} C_{S_{2}}+A_{r} \exp \left(-\frac{E_{a_{r}}}{R T}\right) C_{C O S} C_{\text {total }}$ & 13 \\
\hline 10 & $2 \mathrm{NH}_{3} \leftrightarrow \mathrm{N}_{2}+3 \mathrm{H}_{2}$ & $r_{N H_{3}}=-A \exp \left(-\frac{E_{a}}{R T}\right) P_{N H_{3}}^{1.25}$ & 14 \\
\hline 11 & $2 \mathrm{NH}_{3}+\frac{3}{2} \mathrm{O}_{2} \leftrightarrow \mathrm{N}_{2}+3 \mathrm{H}_{2} \mathrm{O}$ & $r_{N H_{3}}=-A \exp \left(-\frac{E_{a}}{R T}\right) P_{N H_{3}}^{1.25} P_{O_{2}}^{0.75}$ & 14 \\
\hline
\end{tabular}

Table 3. Arrhenius Constants for Reactions

\begin{tabular}{|c|c|c|c|c|}
\hline $\begin{array}{c}\text { Rxn. } \\
\#\end{array}$ & $A / A_{f}$ & $\overline{E_{a} / E_{a_{f}}}$ & $\mathbf{A}_{\mathrm{r}}$ & $\boldsymbol{E}_{a_{r}}$ \\
\hline 1 & $1.774 \times 10^{11}\left(\mathrm{~m}^{3} / \mathrm{mol}\right)^{0.5} / \mathrm{s}$ & $1.88 \times 10^{5}(\mathrm{~J} / \mathrm{mol})$ & $1.53 \times 10^{5}\left(\mathrm{~m}^{3} / \mathrm{mol} \mathrm{s}\right)$ & $9.88 \times 10^{4}(\mathrm{~J} / \mathrm{mol})$ \\
\hline 2 & $5.325 \times 10^{11}\left(\mathrm{~m}^{3} / \mathrm{mol}\right)^{0.5} / \mathrm{s}$ & $2.08 \times 10^{5}(\mathrm{~J} / \mathrm{mol})$ & $3.07 \times 10^{11}\left(\mathrm{~m}^{3} / \mathrm{kmol}\right)^{0.75} / \mathrm{s}$ & $1.88 \times 10^{5}(\mathrm{~J} / \mathrm{mol})$ \\
\hline 3 & $4.728 \times 10^{8}\left(\mathrm{~m}^{3} / \mathrm{mol}\right)^{0.5} / \mathrm{s}$ & $\left.4.60 \times 10^{4} \mathrm{U} / \mathrm{mol}\right)$ & & \\
\hline 4 & $5.532 \times 10^{7}\left(\mathrm{~m}^{3} / \mathrm{mol} \mathrm{s}\right)$ & $\left.1.60 \times 10^{6} \mathrm{U} / \mathrm{mol}\right)$ & & \\
\hline 5 & $1.000 \times 10^{13.2}$ & $48.40(\mathrm{kcal} / \mathrm{mol})$ & & \\
\hline 6 & $1.300 \times 10^{12}$ & $30.00(\mathrm{kcal} / \mathrm{mol})$ & & \\
\hline 7 & $1.000 \times 10^{12}$ & $30.00(\mathrm{kcal} / \mathrm{mol})$ & & \\
\hline 8 & $2.239 \times 10^{12}\left(\mathrm{~m}^{3} / \mathrm{mol}\right)^{0.75} / \mathrm{s}$ & $\left.1.67 \times 10^{5} \mathrm{~J} / \mathrm{mol}\right)$ & $5.02 \times 10^{8}(1 / s)$ & $1.67 \times 10^{5}(\mathrm{~J} / \mathrm{mol})$ \\
\hline 9 & $3.181 \times 10^{2}\left(\mathrm{~m}^{3} / \mathrm{mol} \mathrm{s}\right)$ & $\left.5.58 \times 10^{4} \mathrm{~J} / \mathrm{mol}\right)$ & $2.18 \times 10^{6}\left(\mathrm{~m}^{3} / \mathrm{mol} \mathrm{s}\right)$ & $1.80 \times 10^{5}(\mathrm{~J} / \mathrm{mol})$ \\
\hline 10 & $4.210 \times 10^{-3} \mathrm{~mol} /\left(\mathrm{s} \mathrm{atm}^{1.25} \mathrm{~cm}^{3}\right)$ & $16.50(\mathrm{kcal} / \mathrm{mol})$ & & \\
\hline 11 & $4.430 \times 10^{3} \mathrm{~mol} /\left(\mathrm{s} \mathrm{atm}^{1.75}\right)$ & $40.00(\mathrm{kcal} / \mathrm{mol})$ & & \\
\hline
\end{tabular}

\section{Validation}

Simulation results of molar flow rates were compared with the design data of the Izmit Refinery, Tupras.

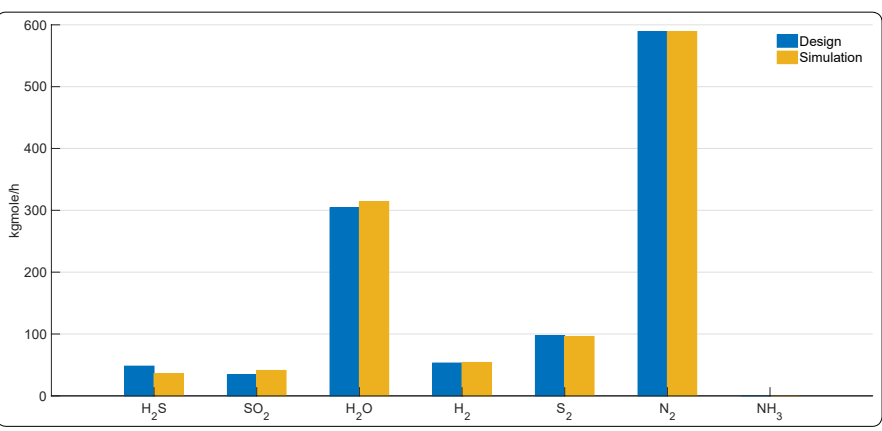

Figure 4. Molar Flow Rate (kgmole/h) of Important Species

figure 4 represents important molecules that are present at the outlet of the reaction furnace in column chart. At the first glance, $\mathrm{H}_{2} \mathrm{~S}$ and $\mathrm{SO}_{2}$ deviate from their design values. $\mathrm{H}_{2} \mathrm{O}_{1} \mathrm{H}_{2}$ and $\mathrm{S}_{2}$ are consistent with the design values with small deviations. Finally, it can be seen that all of the $\mathrm{NH}_{3}$ is converted to $\mathrm{N}_{2}$ as expected. All of the hydrocarbons are consumed and flow rates of $\mathrm{COS}$ and $\mathrm{CS}_{2}$ are found to be less than $0.2 \mathrm{kmol} / \mathrm{h}$, which are negligible compared to above mentioned ones. Thereby, they were not shown in figures. The deviations are because of simplified reaction mechanisms and are negligible in practical perspective.

\section{Effects of Inlet Air Temperature}

Temperature is one of the most important parameters for Sulfur Recovery Process. It directly affects the kinetics and equilibrium. On the other hand, energy consumption and 
production can be altered with simple modifications. Air feed (Air ${ }_{0}$ )is heated from $90^{\circ} \mathrm{C}$ upto $210^{\circ} \mathrm{C}$ and split into two streams; one (Air $\left.{ }_{1}\right)$ is for Reaction Furnace, other one(Air ${ }_{2}$ )for Selective Oxidation Process, as shown in (Figure 5).

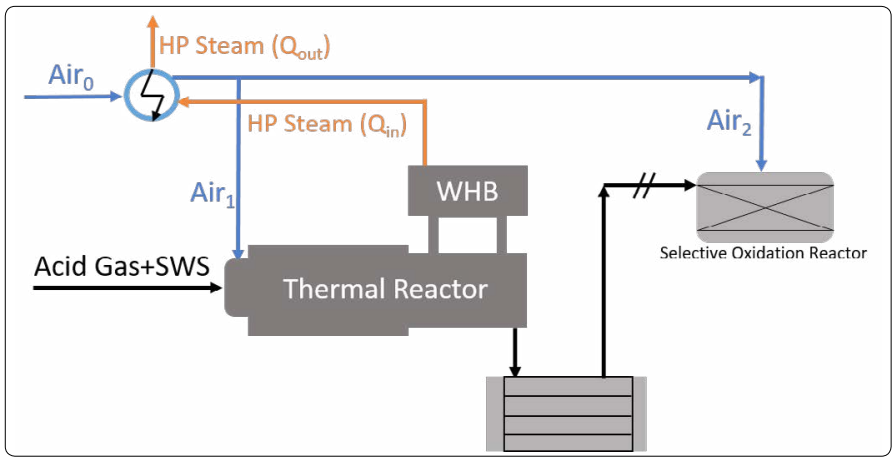

Figure 5. Heat Integration of Sulfur Recovery Unit (Case 1)

Unlike the other SRUs, this unit has heat integration: HP steam obtained from WHB is used to preheat the air. Effects of this heating process is investigated in next sections for entire plant

\section{Reaction Furnace Temperature}

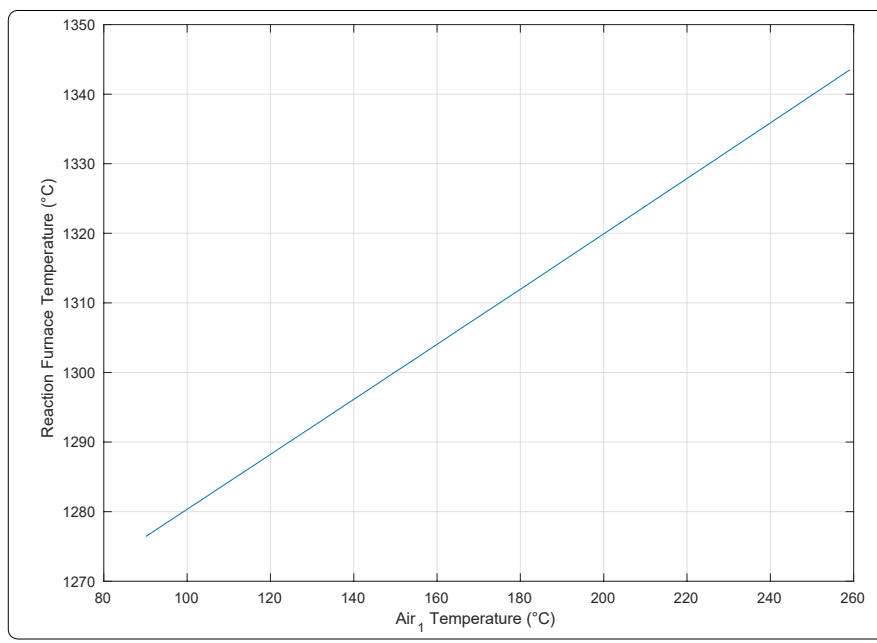

Figure 6. Reaction Furnace Temperature vs. Air Temperature

figure 6 shows that reaction furnace temperature increases as air temperature increases. That is because internal energy of the molecules approaches towards the activation energy.

\section{Sulfur Production}

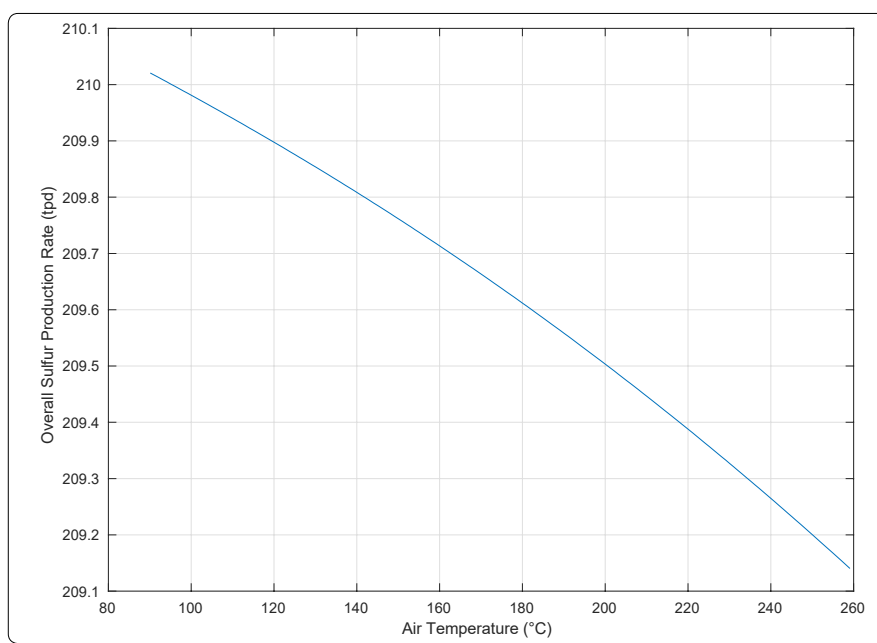

According to Figure 7, change in overall sulfur production is less than 1 ton between 90 and $260^{\circ} \mathrm{C}$. Because the sulfur prices are about $\$ 50 / t$, varying temperature does not have a significant impact from financial perspective.

\section{Catalysts}

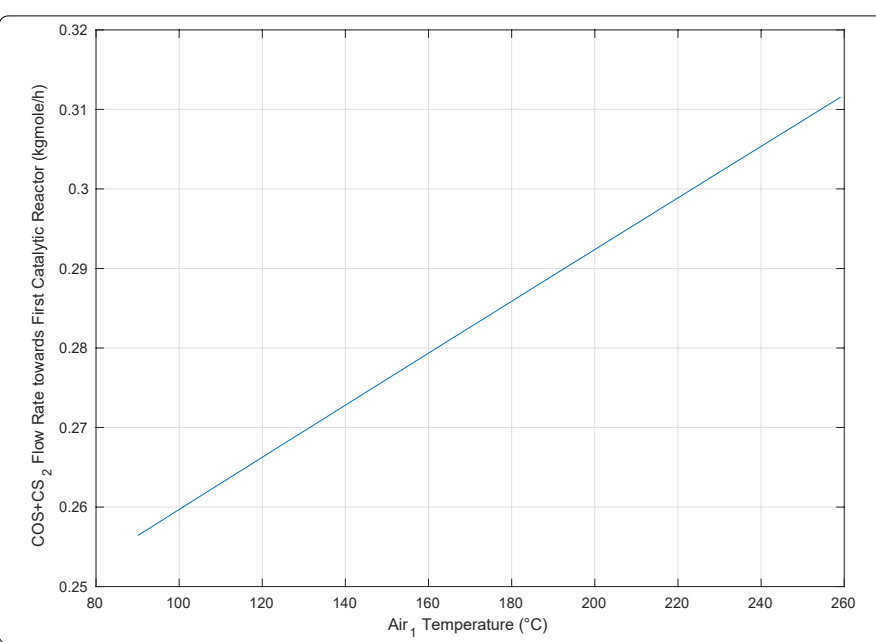

Figure 8. $\mathrm{COS}+\mathrm{CS}_{2}$ Flow towards First Reactor vs. Air ${ }_{1}$ Temperature

As can be seen from Figure 8 increasing air temperature augments $\mathrm{COS}$ and $\mathrm{CS}_{2}$ production, slightly. This increase may not affect the catalysts in short term.

\section{Environmental Impacts}

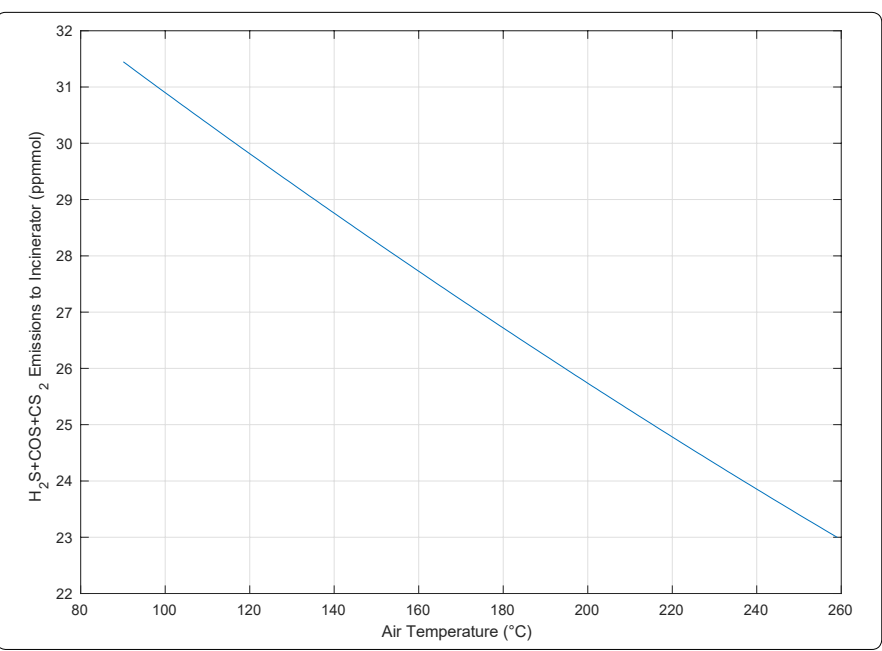

Figure 9. $\mathrm{COS}, \mathrm{CS}_{2}, \mathrm{H}_{2} \mathrm{~S}$ Emission vs.Air Temperature $\left[{ }^{\circ} \mathrm{C}\right]$

The regulations limits mainly $\mathrm{SO}_{2}$ emission. (Figure 9) shows that increasing air temperature from 120 to $260{ }^{\circ} \mathrm{C}$ decreases emissions $23 \%$. This cumulative emission value is read on the stream before the incinerator. Because $\mathrm{COS}, \mathrm{CS}_{2}$ and $\mathrm{H}_{2} \mathrm{~S}$ molecules are oxidized to $\mathrm{SO}_{2^{\prime}}$ and they are considered as pollutants; they have to be controlled carefully.

\section{Energy}

figure 5 shows that air is preheated by using HP steam obtained from WHB. Net power after the preheating process $\left(Q_{\text {in }}-Q_{\text {out }}\right)$ is investigated in this section. The result is shown in (Figure 10).

Figure 7. S Conversion/Production vs. Air ${ }_{1}$ Temperature. 


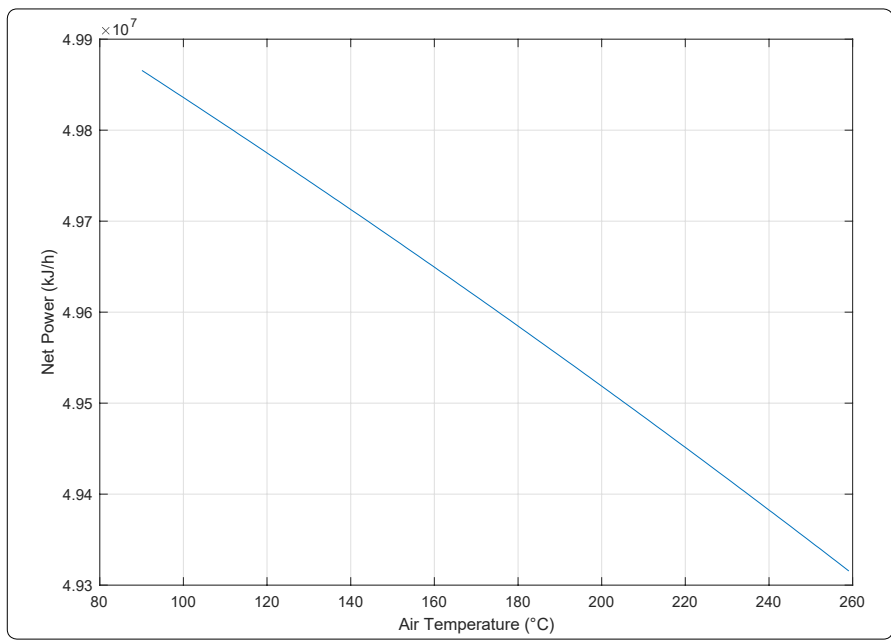

Figure 10. Net Power as $\mathrm{kJ} / \mathrm{h}$ vs. Air Temperature $\left[{ }^{\circ} \mathrm{C}\right]$

According to figure 10, net power decreases as temperature increases. That is because Air is heated completely but used partially (as Air ${ }_{1}$ ) to yield energy. This means, heat is obtained as HP steam, only because of Reaction Furnace, not of Selective Oxidation Reactor. And $\mathrm{Air}_{2}$ is heated unnecessarily. This circumstance is investigated in the next section, in more detail.

\section{Effect of Selective Oxidation Reactor (SOR) on Energy Consumption}

According to previous section, it was shown that air consumes more energy than it actually generates via combustion reactions. That is due to air is completely warmed up but only partially used in furnace, rest is fed to Selective Oxidation Reactor. In this part, comparison between heating the air completely and partially is performed.

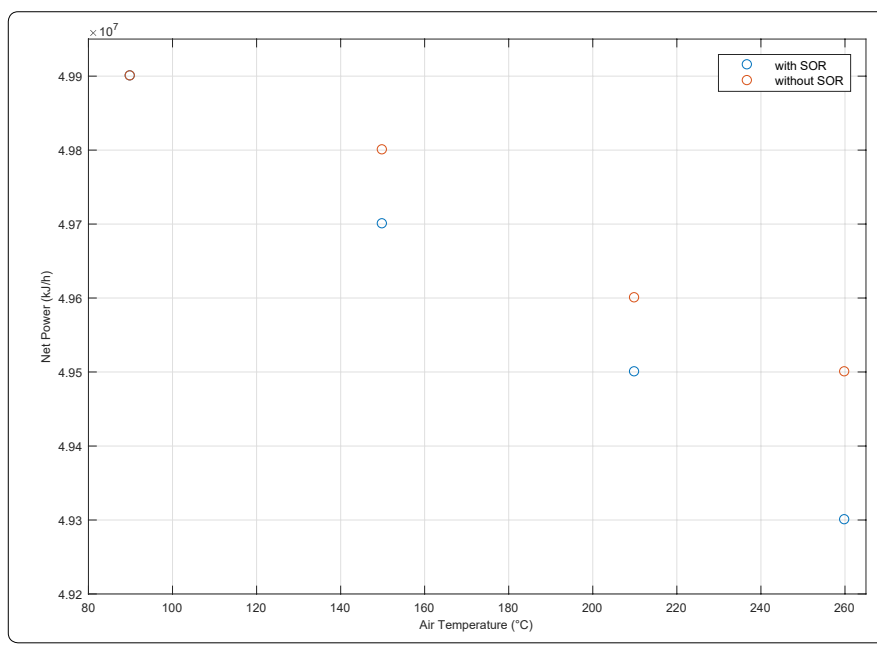

Figure 11. Net Power Obtained from WHB with and without Selective Oxidation Reactor (SOR) at Different Temperatures

Figure 11 shows the impact of selective oxidation reactor. At the first glance, it can be seen that increasing air temperature enhances "Net Power Gap". That is because a part of $\mathrm{Air}_{0}$ is heated unnecessarily. At $210^{\circ} \mathrm{C}$, about 150,000 $\mathrm{kJ} / \mathrm{h}$ power can be saved by de-attaching $\mathrm{Air}_{2}$ stream from the preheater. By assuming $90 \%$ of harvest efficiency, and using average HP steam value of the unit, $\$ 5200$ can be saved per year if the SOR is de-attached from the preheater. (Figures 12 and 13) show two possible configurations to save energy. table 4 summarizes the results of these possibilities.

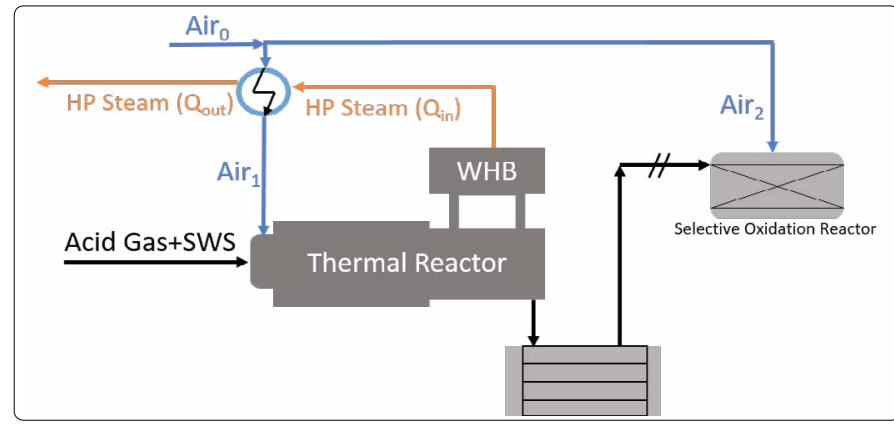

Figure 12. SRU Configuration without Preheating SOR Air (Case 2).

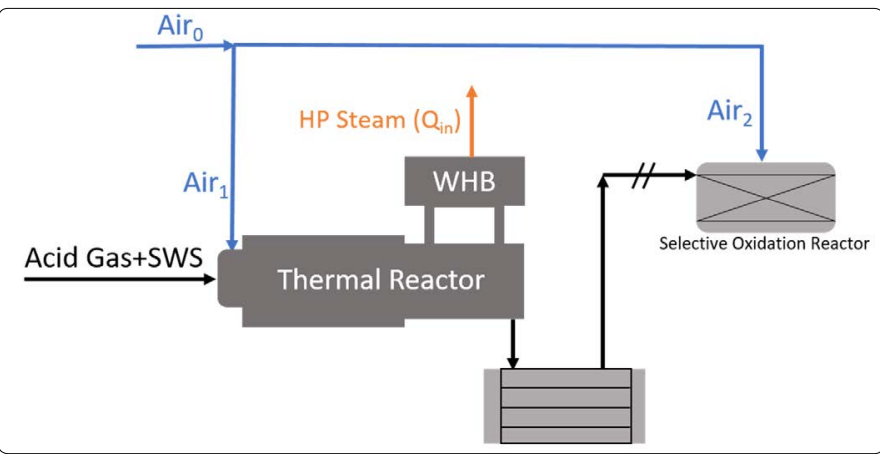

Figure 13. SRU Configuration without Preheating Air (Case 3).

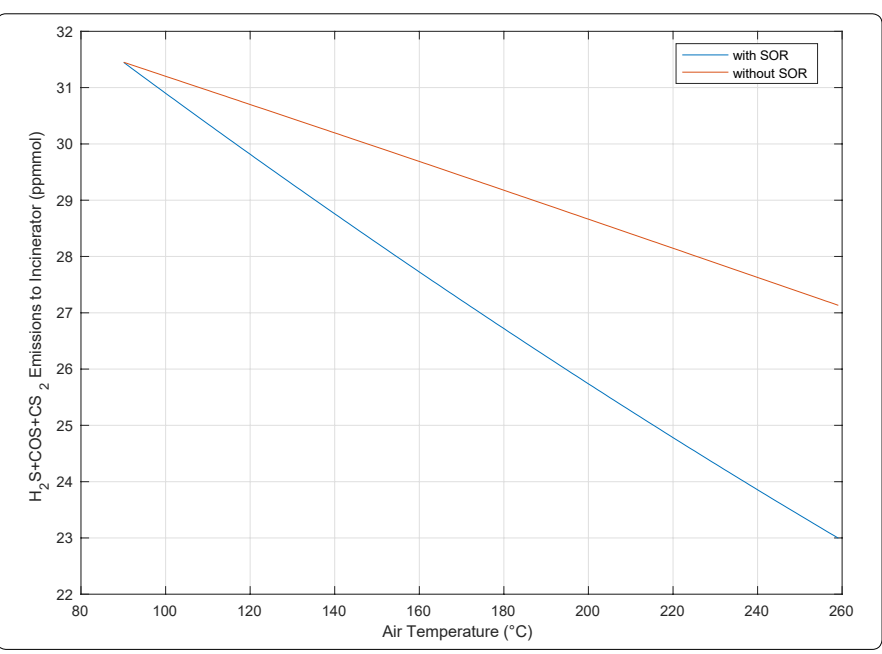

Figure 14. Effects of Preheating Air Feed of SOR on the S-Containing Molecules

Figure 14 shows that increasing temperature decreases the emissions (that go towards the incinerator), which are oxidized into $\mathrm{SO}_{2}$. Changing configuration from design case into Case 2 (not preheating Air ${ }_{2}$ ) increases the emissions about 2 ppmmol at design temperature. Details are given in (Table 4).

Table 4. Comparison of Different Configurations Shown in (Figures 6, 12 and 13).

\begin{tabular}{|c|c|c|c|}
\hline & $\begin{array}{c}\text { Heating Furnace \& } \\
\text { SOR air (Design) }\end{array}$ & $\begin{array}{c}\text { Heating only } \\
\text { Furnace Air }\end{array}$ & $\begin{array}{c}\text { without } \\
\text { Heating }\end{array}$ \\
\hline Air $_{1}$ Temperature [ $\left.{ }^{\circ} \mathrm{C}\right]$ & 210 & 210 & 90 \\
\hline Air $_{2}$ Temperature $\left[{ }^{\circ} \mathrm{C}\right]$ & 210 & 90 & 90 \\
\hline Sulfur Production [tpd] & 209.4 & 209.5 & 210.0 \\
\hline RF Temperature [ $\left.{ }^{\circ} \mathrm{C}\right]$ & 1319.0 & 1319.0 & 1276.4 \\
\hline $\begin{array}{c}\mathrm{COS}+\mathrm{CS}_{2} \text { to } 1^{\text {st }} \text { reactor } \\
{[\mathrm{kmol} / \mathrm{h}]}\end{array}$ & 0.3 & 0.3 & 0.3 \\
\hline $\begin{array}{c}\mathrm{COS}, \mathrm{CS}_{2} \text { and } \mathrm{H}_{2} \mathrm{~S} \text { to } \\
\text { incinerator [ppmmol] }\end{array}$ & 25.3 & 28.4 & 31.4 \\
\hline $\begin{array}{c}\text { Net Power as HP Steam } \\
{[\mathrm{kJ} / \mathrm{h}]}\end{array}$ & $4.95 \mathrm{E}+07$ & $4.96 \mathrm{E}+07$ & $4.99 \mathrm{E}+07$ \\
\hline $\begin{array}{c}\text { EnergySaving [\$/year] } \\
\text { [ }\end{array}$ & 0 & 5238.4 & 13220.8 \\
\hline
\end{tabular}


(Table 4) shows the results of possible configurations. It is possible to save $\$ 5.2 \mathrm{k} /$ year by de-attaching $\mathrm{Air}_{2}$ stream from the preheater and $\$ 13.2 \mathrm{k} /$ year by removing preheating system completely. On the other hand, these operations slightly increase $\mathrm{S}$-containing molecules that are going to be oxidized to $\mathrm{SO}_{2}$. Meanwhile, sulfur production do not change significantly. According to simulation results, without preheating (shown in Figure 13), RF temperature decreases as expected.

\section{Conclusion}

Sulfur content of the crude oils is increasing. Recent developments in the sulfur processing has decreased the sulfur prices. Regulations are becoming stricter for both sulfur contents in fuel and emissions during treatment processes. These circumstances force companies to operate refineries more efficiently.

In this work, a Sulfur Recovery Unit of TUPRAS refinery was modelled by using simplified kinetics. The model predicts the composition of important molecules with minor error values. Furthermore, a simulation performed in order to investigate the effects of air temperature for entire plant. Air temperature was found to have a positive relation with $\mathrm{COS}$ and $\mathrm{CS}_{2}$ flow rates towards the first catalytic reactor. However; due to low concentration, this incline can be neglected in short term. On the other hand, increasing air temperature decreases emissions, sulfur production and net power obtained by means of WHB.

A close research was performed upon the air preheating system and 2 configurations other than the design case was proposed. Regarding to these suggestions, sulfur production as well as concentration of the S-containing molecules may be enhanced slightly by decreasing the temperature of the feed air. By removing preheating system entirely, up to $\$ 13.2 \mathrm{k} /$ year can be saved whilst increasing emissions, slightly. For the sake of simplicity, reverse was not shown (i.e. preheating air much more), however emissions can be decreased by increasing the air temperature. In that case, RF temperature must be considered carefully.

\section{Acknowledgement}

This research was conducted in R\&D Center of Turkish Petroleum Refineries Corporation (TUPRAS), Turkey.

\section{References}

1. Barthe $P$, Chaugny $M$, Roudier $S$, Sancho LD. Best Available Techniques (BAT) Reference Document for the Refining of Mineral Oil and Gas, Industrial Emissions Directive 2010/75/EU. European Commision. 2015.

2. Gary JH, Handwerk GE, Kaiser MJ. Petroleum Refining: Technology and Economics. $5^{\text {th }}$ Edition. CRC Press. ISBN 9780849370380. 2007.

3. Ravikumar A, Raj A, Ibrahim S, Rahman RK, Al Shoaibi A. Kinetic Simulations of $\mathrm{H}_{2}$ Production from $\mathrm{H}_{2} \mathrm{~S}$ Pyrolysis in Sulfur Recovery Units Using a Detailed Reaction Mechanism. Energy \& Fuels. 2016; 30(12): 10823-10834. doi: 10.1021/acs.energyfuels.6b01549

4. Argus World Sulphur Outlook to 2030

5. Recovered Sulfur Prices. Accessed by April 8, 2014.
6. Mao Z, Anani A, White RE, Srinivasan S, Appleby AJ. A modified electrochemical process for the decomposition of hydrogen sulfide in an aqueous alkaline solution. Electrochem Soc. 1991; 138(5): 1299-303. doi: $10.1149 / 1.2085775$

7. Howboldt KA. University of Calgary, Calgary, Alberta, Canada, 1998.

8. Monnery WD, Hawboldt KA, Pollock A, Svrcek WY. New experimental data and kinetic rate expression for the Claus reaction. Chemical Engineering Science. 2000; 55(21): 5141-5148. doi: 10.1016/S00092509(00)00146-9

9. Karan K, Behie LA. CS, Formation in the Claus Reaction Furnace: A Kinetic Study of Methane-Sulfur and Methane-Hydrogen Sulfide Reactions. Ind. Eng.Chem.Res. 2004; 43(13): 3304-3313. doi: 10.1021/ie030515

10. Dryer FL, Westbrook CK. Simplified Reaction Mechanisms for the Oxidation of Hydrocarbon Fuels in Flames. Combustion Science and Technology. 1981; 27(1-2): 31-43. doi: 10.1080/00102208108946970

11. Turns SR, Holman JP, Lloyd J. An Introduction to Combustion Concepts and Applications. 2nd edition. McGraw Hill, Singapore, 2000. 156-159.

12. Karan K, Mehrotra AK, Behie LA. COS-Forming Reaction between CO and Sulfur: A High-Temperature Intrinsic Kinetics Study. Ind. Eng. Chem. Res. 1998; 37(12): 4609-4616. doi: 10.1021/ie9802966

13. Monnery WD, Hawboldt KA, Pollock AE, Svrcek WY. Ammonia pyrolysis and oxidation in the Claus furnace. Ind. Eng. Chem. Res. 2001; 40(1): 144151. doi: $10.1021 / i e 990764 r$

14. Clark PD, Dowling NI, Huang M, Svrcek WY, Monnery WD. Mechanisms of $\mathrm{CO}$ and COS formation in the Claus furnace. Ind. Eng. Chem. Res. 2001; 40(2): 497-508. doi: 10.1021/ie990871

15. Davis $S G$, Joshi AV, Wang $H$, Egolfopoulos $F$. An optimized kinetic model of $\mathrm{H}_{2} / \mathrm{CO}$ combustion. Proceedings of the Combustion Institute. 2005; 30(1): 1283-1292. doi: 10.1016/j.proci.2004.08.252

16. Ghahraloud H, Farsi M, Rahimpour MR. Modeling and optimization of an industrial Claus process: Thermal and catalytic section. Journal of the Taiwan Institute of Chemical Engineers. 2017; 76: 1-9. doi: 10.1016/j.jtice.2017.03.005

17. Jones D, Bhattacharyya D, Turton R, Zitney SE. Rigorous Kinetic Modeling and Optimization Study of a Modified Claus Unit for an Integrated Gasification Combined Cycle (IGCC) Power Plant with $\mathrm{CO}_{2}$ Capture. Ind. Eng. Chem. Res. 2012; 51(5): 2362-2375. doi: 10.1021/ie201713n

18. Karan K, Mehrotra AK, Behie LA. A high-temperature experimental and modeling study of homogeneous gas-phase COS reactions applied to Claus plants. Chemical Engineering Science. 1999; 54(15-16): 2999-3006. doi: 10.1016/S0009-2509(98)00475-8

19. Kazempour $H$, Pourfayaz F, Mehrpooya M. Modeling and multioptimization of thermal section of Claus process based on kinetic model. Journal of Natural Gas Science and Engineering. 2017; 38: 235-244. doi: 10.1016/j.jngse.2016.12.038

20. Manenti F, Papasidero D, Bozzano G, Ranzi E. Model-based optimization of sulfur recovery units. Computers and Chemical Engineering. 2014; 66: 244-251. doi: 10.1016/j.compchemeng.2014.01.019

21. Manenti F, Papasidero D, Frassoldati A, Bozzano G, Pierucci S, Ranzi E. Multi-scale modeling of Claus thermal furnace and waste heat boiler using detailed kinetics. Computers and Chemical Engineering. 2013; 59: 219-225.

22. Mansha M, Saleemi AR, Ghauri BM. Kinetic models of natural gas combustion in an internal combustion engine. Journal of Natural Gas Chemistry. 2010; 19(1): 6-14. doi: 10.1016/S1003-9953(09)60024-4

23. Nabikandi NJ, Fatemi S. Kinetic modelling of a commercial sulfur recovery unit based on Claus straight through process: Comparison with equilibrium model. Journal of Industrial and Engineering Chemistry. 2015; 30: 50-63. doi: 10.1016/j.jiec.2015.05.001

24. Pahlavan M, Fanaei MA. Modeling and Simulation of Claus Unit Reaction Furnace. Iranian Journal of Oil \& Gas Science and Technology. 2016; 5(1): 42-52.

25. Pollock AE. Kinetic Modeling of the Modified Claus Reaction Furnace. 2012. 
26. Sayed AER, Ashour I, Gadalla M. Integrated process development for an optimum gas processing plant. Chemical Engineering Research and Design. 2017; 124: 114-123. doi: 10.1016/j.cherd.2017.05.031

27. Zarei S, Ganji H, Sadi M, Rashidzadeh M. Thermo-kinetic modeling and optimization of the sulfur recovery unit thermal stage. Applied Thermal Engineering.2016; 103:1095-1104.doi:10.1016/j.applthermaleng.2016.05.012
28. Zughbi HD, Razzak SA. Simulation of flow and chemical reactions in a claus sulfur converter. Ind. Eng. Chem. Res. 2005; 44(26): 9828-9839. doi: 10.1021/ie050412m 